\title{
The Praise of God and His Name as the Core of the Second Temple Liturgy
}

\section{Pajunen, Mika Sakari}

2015

Pajunen, M S 2015, ' The Praise of God and His Name as the Core of the Second Temple

Liturgy ' , Zeitschrift für die Alttestamentliche Wissenschaft , vol. 127 , no. 3 , pp. 475-488 . https://doi.org/10.1515/za

http://hdl.handle.net/10138/231806

https://doi.org/10.1515/zaw-2015-0026

publishedVersion

Downloaded from Helda, University of Helsinki institutional repository.

This is an electronic reprint of the original article.

This reprint may differ from the original in pagination and typographic detail.

Please cite the original version. 


\title{
Mika S. Pajunen* \\ The Praise of God and His Name as the Core of the Second Temple Liturgy
}

DOI 10.1515/zaw-2015-0026

Praise of God, alongside the reading of the Law and the sacrificial cult, has always been understood by scholars as a primary element of the liturgical life of the Second Temple period. ${ }^{1}$ Form critics working in the $20^{\text {th }}$ century, like Hermann Gunkel, Sigmund Mowinckel and in the case of praises particularly Claus Westermann, situated the praises of God in the liturgical practice of the Second Temple period most of all by analyzing the Psalms now in the MT Psalter. ${ }^{2}$ Hence, they conceived the liturgical core of the Second Temple to revolve around praise and lament because those two form-critically defined categories of Psalms made up about two thirds of the Psalms in the Psalter. ${ }^{3}$ However, it has also been well recognized that these categories of psalms, and especially lament, cannot form a basis for understanding the liturgy of the late Second Temple period at least from

\begin{abstract}
1 A wide definition of liturgy that tries to avoid preconceptions of what a liturgy could contain is preferred in this study. A similar view has been posited, for example, by Stefan C. Reif, Judaism and Hebrew Prayer: New Perspectives on Jewish Liturgical History (Cambridge: Cambridge University Press, 1993), 71f., who argues that liturgy in Second Temple Judaism could contain, for instance, acts of mystical piety, temple offering, study, benediction or praise, etc. It is acknowledged that when discussing such a long time period there is bound to have been change and variance in the liturgical practices that have also left traces in the textual evidence. Compare, for instance, the changing conceptions of the temple(s); see John Day, ed., Temple and Worship in Biblical Israel: Proceedings of the Oxford Old Testament Seminar, Library of Old Testament/ Hebrew Bible Studies 422 (London: T\&T Clark, 2005). Nevertheless, the basic core of the liturgy is formulated in similar ways in a wide variety of texts depicting the views of authors writing at different times and for separate audiences. Thus, it is possible to speak of a common idea of what was thought of as the center of liturgical life even though it may not capture the exact reality in all places and at all times during this period.

2 Hermann Gunkel, Die Religion in Geschichte und Gegenwart (Tübingen: J. C.B. Mohr, 21930); idem, Einleitung in die Psalmen: die Gattungen der religiösen Lyrik Israels (Göttingen: Vandenhoeck \& Ruprecht, 1933); Sigmund Mowinckel, Psalms in Israel's Worship, trans. D. Ap-Thomas (Nashville: Abingdon, 1962); Claus Westermann, The Praise of God in the Psalms, trans. K. Crim (Richmond: John Knox Press, 1965); idem, Praise and Lament in the Psalms, trans. K. Crim and R. Soulen (Atlanta: John Knox Press, 1981).
\end{abstract}

3 See, for instance, Westermann, The Praise of God, 152-153.

*Kontakt: Dr. Mika S. Pajunen, University of Helsinki. Mika.s.pajunen@helsinki.fi 
around the third century BCE onwards. In fact, it is difficult to ascertain when exactly lament might have had a prominent place in the institutional liturgies. ${ }^{4}$

Regardless of how the place of laments in the earlier part of this period is evaluated, it is obvious that the evidence for new laments similar to those in the MT Psalter grows very weak, or rather almost non-existent, in the late Second Temple period, and other forms of psalms and prayers probably more relevant to contemporary practices are much more prominent in evidence. Such compositions include liturgical texts, like penitential prayers, ${ }^{5}$ and incantations and apotropaic prayers used primarily in exorcisms, ${ }^{6}$ as well as psalms composed for study use as ethical instruction, historical recollections, and from some point in the second century BCE onwards also as prophecies. During the late Second Temple period there is very little evidence of petitions, typically regarded as the main element in a lament. In contrast, praise permeates, or at the very least cushions, almost every liturgical composition from this period. Even penitence is understood as praise of God, as in Nehemiah $9,5,^{7}$ or penitential elements still culminate in praise as in the Words of the Luminaries (4Q504, 4Q506). Situations of distress described in narratives do not evoke pleas for deliverance but praise as in the Song of the Three Young Men, ${ }^{8}$ and it is noteworthy that the psalms inserted into

4 For example, Erhard S. Gerstenberger, «Non-Temple Psalms: The Cultic Setting Revisited, « in The Oxford Handbook of the Psalms, ed. William P. Brown (Oxford: Oxford University Press, 2014): 339-342, associates the psalms of lament and thanksgiving of an individual most of all with the private sphere of life.

5 See, Rodney Werline, Penitential Prayer in Second Temple Judaism: The Development of a Religious Institution, Society of Biblical Literature Early Judaism and Its Literature 13 (Atlanta: Scholars Press, 1998); Judith Newman, Praying by the Book: The Scriptualization of Prayer in Second Temple Judaism, Society of Biblical Literature Early Judaism and Its Literature 14 (Atlanta: Scholars Press, 1999).

6 See, for example, Esther Eshel, »Apotropaic Prayers in the Second Temple Period, « in Liturgical Perspectives: Prayer and Poetry in Light of the Dead Sea Scrolls: Proceedings of the Fifth International Symposium of The Orion Center for the Study of the Dead Sea Scrolls and Associated Literature, 19-23 January, 2000, ed. Esther G. Chazon, Studies on the Texts of the Desert of Judah 48 (Leiden: Brill, 2003): 69-88.

7 It is not claimed that the different prose prayers referred to in this study would necessarily ever have been used in liturgies. Nevertheless, it is held that the settings and basic forms of such prayers cannot have been fundamentally different from the ways such prayers were used in the authors' contemporary liturgies. Moreover, such prayers may have been of even greater importance for slightly later liturgies that could have sought to imitate both the setting and form of such prayers.

8 Whether or not a division should be made between psalms and prayers is not directly relevant for this study because both could have had a liturgical function. Moreover, no strict line of division can be made between them, see, e.g., Eileen M. Schuller, "Some Reflections on the Function and Use of Poetical Texts among the Dead Sea Scrolls, " in Liturgical Perspectives: Prayer 
narrative contexts in the Hebrew Bible, Apocrypha and Pseudepigrapha, as well as the New Testament, are predominantly praises. Furthermore, psalmic descriptions of situations of distress are at this time embedded in formal psalms of praise and thanksgiving as in the Hodayot, rather than forming a separate psalm genre. Thus, if there ever was a balance between praise and lament in liturgies, it does not exist in the late Second Temple period. This seeming decline of the lament and increased emphasis on praise has been noted by scholars quite frequently, ${ }^{9}$ but thus far a link has been missing between the centrality of praise perceivable in the Hellenistic period and the all-encompassing nature of praise in the texts of the Qumran movement from the first century BCE. This is a link that may in part explain why prayer, or during this time more properly praise, came to be seen in early Judaism as an obligation towards God.

These apparent developments in the prominence of praise will be dealt with by first briefly exploring the ways in which the liturgy of the Second Temple period is described particularly in late psalms and prayers in all likelihood deriving from the Hellenistic period and in other books composed during this period that describe liturgical gatherings, like Chronicles, Ezra and Nehemiah. The liturgical core of the Second Temple is described in these texts as the act of praising/ blessing God/his name. This notion is first articulated in several passages in the Psalms where the whole Second Temple liturgy is apparently described in these terms, and thus it is no wonder that Westermann already stressed that the centrality of praise in the total life of the individual and the people in the Second Temple period was akin to the place the concept of faith has in contemporary religion. ${ }^{10}$

After introducing and discussing the centrality of praise in the Hellenistic period, the main point of the study is how the Second Temple liturgy in the second century BCE is given an explicit basis in the creation and how such traditions in turn served an important function in the composition of new liturgical texts, at

and Poetry in Light of the Dead Sea Scrolls. Proceedings of the Fifth International Symposium of The Orion Center for the Study of the Dead Sea Scrolls and Associated Literature, 19-23 January, 2000, ed. Esther G. Chazon, Studies on the Texts of the Desert of Judah 48 (Leiden: Brill, 2003): 180-183; Harm W. M. van Grol, »Psalm, Psalter, and Prayer, « in Prayer from Tobit to Qumran: Inaugural Conference of the ISDCL at Salzburg, Austria, 5-9 July 2003, ed. Renate Egger-Wenzel and Jeremy Corley, Deuterocanonical and Cognate Literature Yearbook 2004 (Berlin: de Gruyter, 2004): $41 \mathrm{f}$.

9 For example, Eileen Schuller, »Prayer at Qumran, « in Prayer from Tobit to Qumran: Inaugural Conference of the ISDCL at Salzburg, Austria, 5-9 July 2003, ed. Renate Egger-Wenzel and J. Corley, Deuterocanonical and Cognate Literature Yearbook 2004 (Berlin: de Gruyter, 2004): 424 f., draws attention to the increase of blessing formulae at Qumran and in Deuterocanonical prayers. 10 Westermann, The Praise of God, 155. 
least in the context of the Qumran movement who took seriously both the obligation itself and the elements tied in with the obligation, viz., election and joint praise with angels. This tradition concerning the origins of the Second Temple liturgy is most prominent in sources from the last centuries BCE, but even if it is not explicitly present in preserved earlier literature, its roots are to be found in the creation account of Genesis 1,1-2,3 and the liturgical praxis of Second Temple period Judaism. These three elements in the formation of the tradition, i.e., its roots, its early transmission, and its slightly later reception, form the three main parts of this study in which they are presented as successive phases of development.

\section{Roots of the Tradition in Scriptural Interpretation and Liturgical Practice}

First the roots of the tradition where the Second Temple liturgy is anchored to the creation of humanity need to be explored. These roots are found above all in the wording of the first Genesis account of creation (Gen 1,1-2,3), which already implicitly contains the notions of the cult, and in the liturgical practices of the Second Temple period, especially discernable in the psalms, as well as descriptions of liturgical activity in narrative contexts. Together these form the scriptural and practical basis from which the later tradition stems.

Fertile ground for later views on the establishing of the liturgy in creation itself is present in the first Genesis account of creation (Gen 1,1-2,3). The prominent place of the Sabbath and its blessing and sanctifying by God is the most explicit of these elements. And while the passage dealing with the Sabbath in Genesis 2,3 does not describe the actual cultic events of the Sabbath day as already taking place from this point onwards, it is only natural that later traditions made this connection much more explicitly than Genesis does. Similarly, while the liturgical elements are not yet present, the festival cycle is referred to in connection with the creation of the luminaries (Gen 1,14), indeed as one of the main reasons the luminaries were created. Thus, while the liturgy itself is not explicitly present in the Genesis creation account, the main cultic days - the Sabbath and the feasts - are, and these references in Genesis 1,19 and 2,3 provided later authors with sufficient grounds to exegetically anchor the beginning of the liturgy to the moment of creation.

Thus, Genesis provides the later authors with a ready platform to introduce the idea of the early beginning of the liturgy more fully, but where does the concept used in later texts to describe the liturgy, that is, blessing and praising God and/ or his name, derive from? At this point it is important to note that throughout the 
analyzed material, and especially in the earlier Psalms, by which I mainly mean the Psalms now in the Hebrew Bible, God himself and his name are explicitly juxtaposed. They are used as parallels in over twenty Psalms and a similar usage can be observed in later psalms and prayers as well (e.g., Ps 7,18; 9,3; 18,50; 22,23; 30,5; 33,21; 34,4; 48,11; 52,11; 54,8; 66,2.4; 72,18-19; 75,2; 86,12; 92,2; 96,1-2; 100,4; $102,22 ; 103,1 ; 105,1 ; 106,47 ; 135,1-3 ; 138,1-2 ; 145,1-2.21 ; 148)$. Thus, in poetic language God and the name of God seem to have been largely interchangeable concepts. ${ }^{11}$ Consequently, when praise of God is mentioned in the following sections, it includes passages that talk of praising or blessing God, his name, or both.

The formulations used by the second century BCE authors to describe the entire liturgy simply by referring to the act of praising God seems to derive from the Second Temple period liturgy, as the blessing and praising of God is the most frequent liturgical formulation in the psalms (e.g., Ps 7,18; 9,3; 18,50; 44,9; 54,8; $61,9 ; 66,2.4 ; 72,19 ; 69,31 ; 92,2-3 ; 103,1 ; 105,3 ; 140,14 ; 149,3)$, which grows even more frequent in slightly later texts, such as the Daily Prayers (4Q503). ${ }^{12}$ It is thus apparently a prominent part of the liturgical life of the Second Temple period and it is explicitly connected in the psalms with the Temple and the cult, for example, in Psalms 22,3; 96,2.8; 100,4; 135,1. The idea that blessing and praising God and his name was something elemental to the Second Temple liturgy is strengthened by the frequent mentions of such activity being done in cultic gatherings in the books of Chronicles and Nehemiah, which certainly reflect the Second Temple period liturgical formulations; notice, for instance, Nehemiah 9,5 where the Levites bless the name of God in a cultic gathering (cf. I Chr 29,10.20; II Chr 2,11; 6,$3 ; 20,26 ; 31,8$; Neh 8,6). Moreover, it is with joyous praise that the first temple is established in the Chronicles, probably a reflection of the Chronicler's own time, and hymns are even placed at the center of warfare (II Chr 20,22). Finally, it is praise that characterizes the final two books of the current Psalter, which are frequently thought of as the latest parts of it.

Attention can also be drawn, for instance, to the role of David as the establisher of the temple liturgy, which is an emphasis of the Chronicler(s) (see, e.g., I Chr 29). This idea was then accepted and even elaborated in further traditions. For instance, the Praise of the Ancestors in Ben Sira 47,8-10 mentions that David sang praises and established the year round liturgy that is characterized in the

11 See also, Travis J. Bott, »Praise and Metonymy in the Psalms, « in The Oxford Handbook of the Psalms, ed. William P. Brown (Oxford: Oxford University Press, 2014): 134-136.

12 For a list of passages from late Second Temple period texts containing the blessing formula of the divine name, see Reuven Kimelman, »Blessing Formulae and Divine Sovereignty in Rabbinic Liturgy, « in Liturgy in the Life of the Synagogue: Studies in the History of Jewish Prayer, ed. Ruth Langer and Steven Fine, Duke Judaic Studies 2 (Winona Lake, Ind.: Eisenbrauns, 2005): 4-6. 
passage as a praise of God's holy name. Similarly, in David's Compositions (11QPs ${ }^{\text {a }}$ 27,4-5) it is said that David wrote 3600 songs of praise. The word »Tehilim « used of these psalms is important because it is best known as the title of the current Book of Psalms. ${ }^{13}$ Such was not yet the case when David's Compositions were written, but it is important that the word used for psalms of praise became the general designation of a collection of psalms where only about a third of the psalms are classified as praises by scholars and that the use of the word »Tehilim « in David's Compositions is already an example of such a usage where praise is selected to characterize the psalms that David wrote. It says something about the prominence of praise during and also after this period.

Thus, the liturgy established by David according to Chronicles was seen as something that could at least in Ben Sira's view be characterized as praises of the name of God. There is no reason to assume that the description of this Davidic liturgy would be somehow fundamentally different from the liturgy of Ben Sira's own time. Nevertheless, there are also several passages in the Psalms where the whole Second Temple liturgy is apparently described in these terms. Psalm 106,47 formulates the hope for the return of the exiles and the ensuing renewal of the liturgy by speaking of being again able to praise the name of God; Psalm 122,4 speaks of the tribes of Israel going up to Jerusalem in order to praise the name of God; Psalm 138,2 in turn relates a practice of bowing down toward the temple and praising the name of God; and finally Psalm 145,1-2 talks of blessing and praising God and his name as something the psalmist will do every day, and similar views are also displayed, for instance, in Psalm 92,2-3. Therefore, the least that could be said is that praising God was a prominent part of the Second Temple liturgical life, but it seems that it was also possible to speak of the whole liturgy in a nutshell as praising and blessing the name of God. In fact, an analysis of passages in the Psalms speaking about the inability to praise God (e.g., Ps 119,175) leads Jörg Jeremias to conclude that giving praise is displayed in these texts as the most elementary characteristic of being alive. It forms the basis of any life, and hence if there is no giving of praise, there is no life. ${ }^{14}$

13 The psalm titles are not of much use in categorizing individual psalms in the late Second Temple period; see Eileen Schuller, »The Use of Biblical Terms as Designations for Non-Biblical Hymnic and Prayer Compositions, « in Biblical Perspectives: Early Use \& Interpretation of the Bible in Light of the Dead Sea Scrolls: Proceedings of the First International Symposium of the Orion Center, 12-14 May 1996, ed. Michael E. Stone and Esther G. Chazon, Studies on the Texts of the Desert of Judah 28 (Leiden: Brill, 1998): 207-222.

14 Jörg Jeremias, »Worship and Theology in the Psalms, « in Psalms and Liturgy, ed. Dirk J. Human and Cas J. A. Vos, Library of Old Testament/Hebrew Bible Studies 410 (London: T\&T Clark, 2004): 99. Cf. Westermann, The Praise of God, 155-161. 
However, this praise of the name of God is in these texts still primarily connected with the temple and the covenant community of Israel, even though a few psalms express the hope of this praise spreading to the whole world as in Psalm 113,1-3. The temple and the people of Israel are hence at the center of this practice, but there are a couple of Psalms that call on the whole of creation to bless God the creator and his name, such as Psalm 103,20-21, Psalm 145,10.21, and Psalm 148,3.13. While these psalms do not connect the praise with the actual event of creation they contain the idea that the whole of creation should bless God their creator, which could then be retrojected by later authors to the creation itself in view of the creation account in Genesis 1,1-2,3. Therefore, to conclude this section, the first account of creation in Genesis provides a suitable context for later interpretations of when the liturgy started, whereas the liturgical praxis of the Second Temple period, reflected in the psalms and the narratives stemming from this period, dictated how the liturgy was characterized in the later texts.

\section{Birth and Transmission of the Tradition in Second Century BCE Texts}

In the texts from around the second century BCE the tradition explicitly connecting the cultic responsibility to praise God with the creation is first attested in written form. It is most often presented as a divine obligation laid on humanity at the same time as the mandate to rule and the bounty of food, which follow directly after the creation of humanity in Genesis (Gen 1,27-29). Thus, for example, in the Admonition on the Flood God declares: "Let all those who do my will eat and be satisfied and let them bless my [holy] name, " 4 Q370 I 1-2) and the Festival Prayers go as far as saying: we will praise Your name forever [and ever] because for this purpose You created us (1Q34 3i 6-7). Ben Sira likewise connects the praise of the divine name explicitly with the creation of humanity (Sir 17,9-10), and also 4QNon-Canonical Psalms B (4Q381 I 7-8) refers to something to be done each day, month and year between the privileges given by God to humanity at creation, i.e., the giving of a bounty of food and the mandate to rule, but exactly how this apparent reference to the cult is formulated is unfortunately not extant. ${ }^{15}$ Finally, in Jubilees 2,21 eating, drinking and blessing God are given

15 See further, Mika S. Pajunen, The Land to the Elect and Justice for All: Reading Psalms in the Dead Sea Scrolls in Light of 4Q381, Journal of Ancient Judaism Supplements 14 (Göttingen: Vandenhoeck \& Ruprecht, 2013), $153 \mathrm{f}$. 
as an ordinance decreed at the creation about how to properly keep the Sabbath day. But Jubilees also adds to this concept the idea that this blessing of God is to be done together with the angels, which seems to have been an idea quite influential in slightly later traditions.

Thus, there are a number of texts that represent slightly different time periods and views of diverse authors that all connect the concept of praising God with the creation of humankind. As already indicated in the previous section, the centrality of the concept of praising God derives from the liturgical formulations of the Second Temple period and may have been used already in some of the earlier texts as a way of describing the whole liturgy. This convergence of evidence strongly implies that the concept of blessing and praising the divine crystallizes what the Second Temple liturgy was in essence all about, and in the texts from around the second century BCE this liturgy was explicitly anchored in the creation.

But in these texts the liturgical practice first of all becomes tied in with the already mentioned notion that the praising is to be carried out together with the angels, but in addition it becomes connected with the concept of divine election, which is most directly stated in some of the Greek manuscripts of Ben Sira 17,10, which read: "and the elect shall praise his holy name. «16 The same connection between election and praise is made by practically all of the above sources, but usually in a more implicit way. Most of the above texts, Ben Sira 17,10 (regardless of which available version is read), ${ }^{17}$ the Admonition on the Flood and probably also the Festival Prayers and 4QNon-Canonical Psalms B claim that the praising of God was to be practiced first by all of humanity, which were the first elect of God. But when they failed as the elect because of repeated transgressions, the obligation to continually bless the name of God fell to the next chosen of God, the people of Israel.

Ben Sira makes this connection with election by first relating the creation of humanity and their privileges as the rulers of all creatures, as well as obligations, as granted at creation, including praise of God, and then proceeding to the election of Israel (Sir 17,1-18). The Admonition on the Flood (4Q370 I-II) deliberately juxtaposes the rebellion of humankind with the deeds of Israel in the wilderness (and possibly also the divine granting of food on both occasions) and the transgressions of the pre-Flood humanity and by presenting the Flood as a warning

\footnotetext{
16 See, e.g., Conleth Kearns, The Expanded Text of Ecclesiasticus: Its Teaching on the Future Life as a Clue to Its Origin, ed. Pancratius Beentjes, Deuterocanonical and Cognate Literature Studies 11 (Berlin: de Gruyter, 2011), 147-149.

17 Cf. Marko Marttila, Foreign Nations in the Wisdom of Ben Sira: A Jewish Sage between Opposition and Assimilation, Deuterocanonical and Cognate Literature Studies 13 (Berlin: de Gruyter, 2012), 42-79.
} 
example of the punishment for such transgressions. The Festival Prayers (1Q34 3) in turn talk about all the privileges of humankind at creation one after another, viz., food, dominion, praise of God, and election, as well as mentioning the rejection of humankind because of their transgressions and turning immediately after this to the election of Israel as the chosen people. Similarly, in 4QNon-Canonical Psalms $B$ the first psalm is about humanity as the chosen species (4Q381 I 1-II 10), including the blessings granted to them and the flood as punishment for their transgressions, followed in the next psalm by an account of the election and finally also rejection of Israel (4Q381 II 11-IV 6). ${ }^{18}$ Jubilees (Jub. 2,16-33) is the notable exception in this respect as it obviously takes part in this on-going discussion on election by stating that the keeping of the Sabbath day was constituted at creation, but it was nevertheless only ever meant for the people of Israel, i.e., the establishment of the Sabbath was made in anticipation of the later election of Israel who would then observe it together with the angels. Thus, in this way Jubilees denies that humanity as a whole was ever elected by God, which is also evident in the way Adam and Noah already anticipate the sacrificial cult of Israel, the Garden of Eden is the first sanctuary, etc. Most of the other texts also appear to maintain that Israel continued to be the elect people after humankind failed, but at least 4QNon-Canonical Psalms $B$ already transferred the elect status to a smaller group within Judaism, ${ }^{19}$ which is something that becomes more frequent in the next phase of the transmission of the tradition.

\section{Reception of the Tradition in the Qumran Movement}

In the first century BCE most of the available evidence concerning liturgical practices comes from texts connected with the Qumran movement, like the Hodayot, Berakhot, Songs of the Sage, possibly Songs of the Sabbath Sacrifice and the Barkhi Nafshi. There are also other manuscripts from the Dead Sea Scrolls where the blessing of God's name is connected with further liturgical times in several probably non-sectarian liturgical works, for instance, 4Q408, 4Q409, and 4Q512. Nevertheless, the psalms of the Qumran movement stand out through how all-encompassing the praise of God has become in them. In these texts the praising and blessing elements permeate the whole liturgy in such a manner that even the pro-

18 Pajunen, The Land to the Elect, 143-158.

19 Ibid., 300-303. 
tective songs against the demons (4Q510 and 4Q511) are grounded on terrifying the evil spirits by praising the name of God. The Qumran group's own psalms are, with very minor exceptions, all based on praise and many, if not most, of them have a communal perspective. Absent are the individual and communal laments that make up almost a third of the current MT Psalter. ${ }^{20}$ Some of the elements familiar from laments, such as descriptions of a situation of distress, are found in the movement's psalms like the Hodayot. But they are embedded as individual elements into contexts of praise rather than forming a liturgical category of their own. ${ }^{21}$ Another striking detail is the sheer number of new praise-oriented psalms, Songs of the Sabbath Sacrifice, Songs of the Sage, the Barkhi Nafshi hymns and many of the Hodayot are mostly liturgical pieces and they are all represented by many collections of different sizes. This shift or new emphasis on praise in liturgies is quite evident, for instance, in the Song of the Maskil in the Community Rule, which emphasizes the role of praise and blessing in liturgy as the response to practically all occasions of everyday life (1QS 10,1-17). ${ }^{22}$

But while the Qumran movement took the traditional liturgical formulations concerning the praising of God and probably even elaborated upon their use, perhaps the most interesting part of the reception is that they took over the ideas about the praising and blessing of God's name belonging to the elect community and that the liturgy was to be done together with the angels. Such passages are found, for instance, in the Hodayot (e.g., 1QH ${ }^{\mathrm{a}}$ 11,23) and the Songs of the Sage (4Q511 8 8-9), but are most prominent in the Berakhot and the Songs of the Sabbath Sacrifice. A passage quite well in line with the traditions of the previous century is found in $1 \mathrm{QH}^{\mathrm{a}}$ 11,22-23: "And for man, You have allotted an eternal destiny with the spirits of knowledge, to praise Your name together with shouts of joy, and to recount Your wonders before all Your creatures. « $^{23}$

However, much more influence of the tradition and its growth is demonstrated by the Berakhot. These are at least two manuscripts, 4Q286 and 4Q287, that contain parts of a ritual that has frequently been connected with the annual covenant renewal ritual described in the Qumran Community Rule. The largest

20 For example, according to Carleen Mandolfo, »Language of Lament in the Psalms, « in The Oxford Handbook of the Psalms, ed. William P. Brown (Oxford: Oxford University Press, 2014): 115, the MT Psalter has 42 laments.

21 Cf. Daniel Falk, »The Contribution of the Qumran Scrolls to the Study of Ancient Jewish Liturgy, « in The Oxford Handbook of the Dead Sea Scrolls, ed. John J. Collins and Timothy H. Lim (Oxford: Oxford University Press, 2010): 633.

22 Cf. Falk, »The Contribution of the Qumran Scrolls«: 628-629.

23 Translation by Michael Wise, Martin Abegg and Edward Cook, »Hodayot, Hodayot-like, and Similar Texts, « in Dead Sea Scrolls Reader 5: Poetic and Liturgical Texts, ed. Donald W. Parry and Emanuel Tov (Leiden: Brill, 2005). 
extant parts of the ritual in the Berakhot consist of blessings directed to God (4Q286 1ii-7i and 287 1-5), curses against Belial and his followers (4Q286 7ii and 287 7-10), and several cases of community legislation (4Q286 20ab, 13-17 [not 16], possibly 4Q289). The brief discussion here will be confined to the blessings. Unlike parts of the ritual in 1QS, and the earlier texts dealt with in this study, the Berakhot are not centered on Israel as the covenant community. Actually, none of the fragments of $4 \mathrm{QBerakhot}$ contains a single mention of the law, the covenant, Israel, the people or any figures connectable to it, such as Abraham, Moses or Aaron. Indeed there is a surprising absence of the nation's past and any notion of its election in 4QBerakhot. Instead, all of the extant blessings are about God's different works in creation and for these the elect community of the Yahad praises the name of God together with the angels (4Q286 2 and 7i). ${ }^{24}$ Thus, the blessings of 4QBerakhot contain exactly what texts like Jubilees and Ben Sira described in the previous century as an obligation of the elect, the praise of God's name for his works in creation by his chosen ones together with the angels. But unlike before, the elect blessing God are no longer the entire covenant community of Israel, but the Yahad. Similar motifs are also found in the Songs of the Sabbath Sacrifice where the praise of God together with the angels is the central concept of the whole liturgy. But the Songs of the Sabbath Sacrifice do not focus on the creation but rather on the different angelic beings offering praise with the elect earthly community, and on how the liturgy itself unfolds in the heavens.

Therefore, it seems that the Qumran movement took seriously the notions of the authors in the preceding century or so, that the elect were meant to bless the name of God together with the angels, and formulated new liturgical texts for various purposes that contained these central ideas. It is also possible that the strong emphasis on praise as an answer to almost every situation in life should be seen against this background. After all, the texts in the preceding century did formulate praising God as a major responsibility to be carried out each day, and when these texts were read side by side with the Psalms describing the centrality of praise in the life of the individual and the community, they might have provided the Qumran movement with a hermeneutical key to see nearly all liturgy through praise. But was such an emphasis on praising God a Qumran specialty? Probably not, at least not entirely, because the general practice of the Second Temple period liturgy plausibly remained praise oriented and the anchoring to the creation was done in texts mostly meant to influence a larger group of people,

24 Mika S. Pajunen, „Creation as the Liturgical Nexus of the Blessings and Curses in 4QBerakhot, « in Ancient Readers and their Scriptures: Reading the Hebrew Bible and its Versions in Jewish and Christian Antiquity, ed. Garrick V. Allen and John A. Dunne (forthcoming 2015). 
not just some smaller assemblies. And even though comparative evidence from the last century BCE is largely lacking, it should be noted that the idea that praises are a communal obligation ordained by God has relevance, for instance, on recent discussions in the field of Rabbinic studies where it has been argued by some that communal prayer as an obligatory service to God was an innovation of the rabbis. ${ }^{25}$ In light of the developments just discussed, it seems that the idea of praise as an obligatory service to God was first formulated several hundred years before the rabbis. ${ }^{26}$ If such an influence is to be taken seriously into consideration then it is plausible that the tradition about a divine obligation to praise God was also accepted by other Jewish groups, not just the Qumran movement.

\section{Conclusions}

The evidence gathered in this study from different authors and from groups representing diverse interests throughout the Second Temple period, and particularly from the Hellenistic period onwards, demonstrates the centrality of praise in the liturgical practice of this period. Indeed, the concept of praising and blessing the divine crystallizes the very essence of the Second Temple liturgy, and it may hence also be seen as one of the central pillars of the Jewish religion. The praise of God was actually perceived as so elemental to everyday life that in the second century BCE it was explicitly formulated as an obligation of the elect towards God that had been in place from the very moment of creation.

What can be seen when looking at the overall development of this tradition connecting the praising and blessing of God and his name with the creation is that the tradition probably begun with exegetical activity that took the scriptural basis available for such an interpretation in Genesis 1,1-2,3 and combined it with the central aspect of the liturgical practice of the Second Temple period, the praise of God. After the tradition was thus formulated, it was early on incorporated into a discussion about divine election and in Jubilees was also transformed from a purely earthly praise into a liturgy carried out by the elect together with the angels. These innovations in turn then influenced the making of new liturgical texts, at least in the Qumran movement, thus completing a cycle where the

25 See further, Falk, »The Contribution of the Qumran Scrolls«: 622.

26 Whether or not praise is seen as part of prayer is a matter of definition. A narrow definition of prayer only takes into account material with supplications, but I agree with scholars who defend a broader definition of prayer that also includes praise; see, for example, van Grol, »Psalm, Psalter, and Prayer«: 42-56; Schuller, »Prayer at Qumran«: $415 \mathrm{f}$. 
anchoring of the Second Temple liturgy in creation actually in the end creates liturgical texts used outside the temple setting and with no explicit connections with the earthly temple and the people of Israel as a whole. Rather the small elect community of the Yahad formulated nearly all its own psalms as praises and participated in the angelic liturgy taking place at the heavenly temple, praising and blessing the name of God together with the angels, thus fulfilling the divine obligation to the elect given already at creation.

Abstract: Das Lob Gottes wurde schon immer als wichtigstes Element des liturgischen Lebens am 2. Tempel verstanden. Formkritiker haben dieses Moment der liturgischen Praxis vor allem durch die Analyse der Psalmen nachgezeichnet. Demgegenüber erscheint die Rolle der Klage zumindest in der späten Phase des 2. Temepls randständig. Allerdings fehlt ein Bindeglied zwischen der hellenistischen Phase der Liturgie und dem Lob in den Qumran Texten des 1 Jh. v. Chr. Der Blick auf das Motiv der Schöpfung erschließt dieses Bindeglied und erklärt zugleich, warum das Lob als Verpflichtung Gott gegenüber verstanden wurde.

Zusammenfassung: Praise of God has always been understood by scholars as a primary element of the liturgical life of the Second Temple period. Form-critics have situated the praises of God in the liturgical practice of the period most of all by analyzing the Psalms now in the MT Psalter. However, at least in the late Second Temple period the role of laments seems to be marginal. Thus far a link has been missing in scholarship between this centrality of praise perceivable in the liturgical practice of the Hellenistic period and the all-encompassing nature of praise in the texts of the Qumran movement from the first century BCE. This is a link that may in part explain why prayer, or during this time more properly praise, came to be seen in early Judaism as an obligation towards God. This question is explored by investigating how the Second Temple liturgy is in many texts from the second century BCE given an explicit basis in the creation, and how such traditions in turn served an important function in the composition of new liturgical texts.

Résumé: La louange de Dieu a toujours été comprise par les exégètes comme un élément essentiel de la vie liturgique de la période du Second Temple. A l'aide de la critique des formes, certains exégètes ont situé les louanges de Dieu dans la pratique liturgique de cette période, en analysant surtout les Psaumes actuellement présents dans le psautier du TM. Le rôle des lamentations, en revanche, semble marginal, au moins dans la période tardive du Second Temple. Jusqu'à présent la recherche n'a pas établi de lien entre la centralité de la louange perceptible dans la pratique liturgique de la période hellénistique et l'importancede 
la louange dans les textes qumrâniens du premier siècle av. J.-C. Ce lien pourrait expliquer, en partie, pourquoi la prière, ou à plus proprement parler la louange, a été de plus en plus perçue, durant cette période, comme une obligation envers Dieu dans le judaïsme primitif. Cette question est explorée à travers l'analyse de nombreux textes du deuxième siècle av. J.-C. qui montrent comment la liturgie du Second Temple a été basée explicitement sur la Création et comment de telles traditions ont occupé en retour une place importante dans la composition de nouveaux textes liturgiques. 